\title{
First report of Ralstonia pseudosolanacearum in the Lao PDR
}

\author{
K. B. Ireland ${ }^{1}$ - B. S. Weir ${ }^{2}$ • E. J. Cother ${ }^{3} \cdot$ S. Phantavong $^{1}$ • P. Phitsanoukane ${ }^{1}$ \\ K. Vongvichid ${ }^{1}$ - P. P. Vongphachanh ${ }^{4}$ - P. Songvilay ${ }^{4} \cdot$ K. Chittarath ${ }^{4} \cdot$ S. Sayapatha ${ }^{4}$. \\ J. Walsh ${ }^{4}$ - S. Turner ${ }^{1}$ - D. Park ${ }^{2}$ L. A. Tesoriero ${ }^{5}$ - S. Vilavong ${ }^{1}$ - G. S. Duckitt ${ }^{1}$. \\ L. W. Burgess ${ }^{6}$
}

Received: 29 June 2016 / Accepted: 10 November 2016/Published online: 16 November 2016

(C) Australasian Plant Pathology Society Inc. 2016

\begin{abstract}
Ralstonia pseudosolanacearum is reported for the first time from the Lao PDR. Typical symptoms of wilt and vascular exudate were observed in potatoes and tomatoes in Paksong district, Champasak province. Pathogenicity was proven and identification was based on symptoms, commercial diagnostic test kits and sequence of the egl gene.
\end{abstract}

Keywords Bacterial wilt $\cdot$ Potato $\cdot$ Pseudomonas

solanacearum $\cdot$ Ralstonia solanacearum

Ralstonia solanacearum (sensu lato) is a widely distributed bacterial pathogen in tropical, sub-tropical and temperate countries causing vascular necrosis and wilt in a wide range of host plants (Hayward 1994). Safni et al. (2014) revised the taxonomy of the Ralstonia solanacearum species complex, describing the new species Ralstonia pseudosolanacearum, which encompassed the diversity of the previously recognised
K. B. Ireland
k.b.ireland@gmail.com

1 Agriculture Section, Provincial Agriculture and Forestry Office, Thaluang Village, Pakse, Champasak, Lao People's Democratic Republic

2 Landcare Research, Private Bag 92170, Auckland 1142, New Zealand

3 PO Box 2117, Orange, NSW 2800, Australia

4 Plant Protection Centre, Nahai Village, Hatsaifong District, Vientiane Capital, Lao People's Democratic Republic

5 Central Coast Primary Industries Centre, New South Wales Department of Primary Industries, University of Newcastle, Ourimbah, NSW, Australia

6 Faculty of Agriculture and Environment, The University of Sydney, Sydney, NSW, Australia phylotypes I and III of Ralstonia solanacearum. Over 200 plant species are susceptible to these races of the pathogen, with the most economically important hosts in the family Solanaceae (Hayward 1994; Kelman 1953). Symptoms of infection are often of a vascular wilt, with bacterial streaming or ooze from a cut stem section being the most common clue to a presumptive diagnosis (Kelman 1953). Higher temperatures (24-35 ${ }^{\circ} \mathrm{C}$ ) favour the disease, as does wet weather and high soil moisture levels (Nesmith and Jenkins 1985).

Typical symptoms of bacterial wilt caused by $R$. solanacea rum (sensu lato) were first observed in a potato crop (Fig. 1) in the Paksong district, Champasak province of the Lao PDR in 2009 during the first national survey of plant diseases. Tests for bacterial ooze, as illustrated in Burgess et al. (2008), were positive. During the second national survey in 2010 symptoms of bacterial wilt were observed in tomato at the then Coffee Research Centre (15 10' 25.93" N; $106^{\circ} 5^{\prime} 50.45^{\prime \prime} \mathrm{E} ; 1900 \mathrm{~m}$ alt.), $35 \mathrm{~km}$ east of Pakse, and the test for bacterial ooze was positive. Small potato tubers in cool storage at the Centre were also surveyed for disease and the typical browning symptoms caused by infection with $R$. solanacearum (sensu lato) were found commonly in the tubers (Fig. 2a). Samples of diseased tomato stems and the potato tubers were tested for the presence of $R$. solanacearum (sensu lato) using the Pocket Diagnostic $®$ test kits for $R$. solanacearum and all were positive (Fig. 2b).

In August 2013, typical symptoms of bacterial wilt on tomatoes growing under polyhouse production were again observed at a large vegetable farm in Paksong district on the Bolaven plateau (15 $15^{\circ} 7.00^{\prime \prime} \mathrm{N}$; $106^{\circ} 17^{\prime} 32.70^{\prime \prime} \mathrm{E}$; $2300 \mathrm{~m}$ alt.). Infected plants presented with symptoms of green wilt (Fig. 3a), adventitious roots (Fig. 3b) and a positive bacterial ooze test. An immunostrip assay from Agdia ${ }^{\circledR}$ was used to confirm putative diagnosis of $R$. solanacearum (sensu lato) in the field. Samples of diseased stems were collected for 


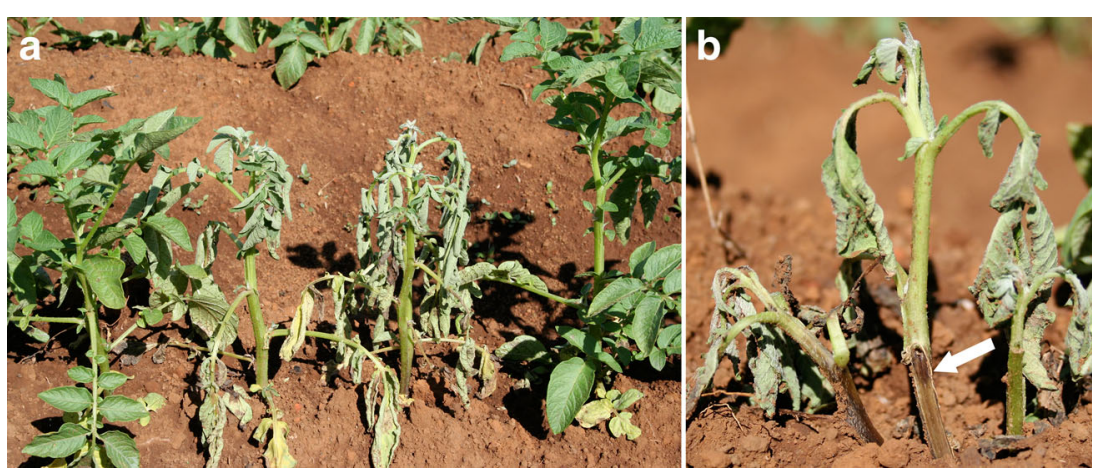

Fig. 1 Bacterial wilt symptoms caused by Ralstonia solanacearum (sensu lato) observed on potato (Solanum tuberosum) in Paksong District, Champasak province, Lao PDR in 2009. (a) Wilting potatoes, surrounded by non-symptomatic plants. (b) Split stem symptoms (indicated by arrow), revealing serious vascular discolouration isolation of the putative pathogen. The stem sections were washed gently in sterile water, immersed briefly (1 sec) in $70 \%$ ethyl alcohol (ETOH), immediately rinsed in sterile water, and then macerated in a drop of sterile water on a sterile glass microscope slide. A loop was used to collect some of the water solution surrounding the macerated tissue and this was streaked onto Sucrose Peptone Agar (SPA) and incubated at room temperature. Consistent bacterial colonies developed from all streaks. Colony growth was examined macroscopically and a colony typical of virulent $R$. pseudosolanacearum, white-coloured with a custard-like consistency, was transferred to SPA and purified. Identity of the purified culture was confirmed using the Agdia ${ }^{\circledR}$ field test kit and forwarded to the International Collection of Microorganisms from Plants (ICMP), Landcare Research, Auckland, New Zealand for confirmation of identification by sequencing. It was accessioned as ICMP 20038 and preserved cryogenically in liquid nitrogen (http://scd.landcareresearch.co.nz/Specimen/ICMP_20038). The same isolate was tested for pathogenicity.

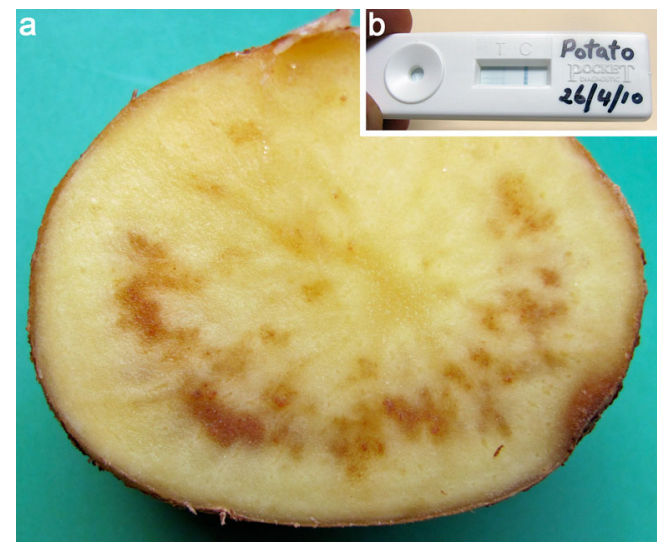

Fig. 2 (a) Vascular discolouration observed in a seed potato tuber (Solanum tuberosum) found at the Coffee Research Centre, Champasak province, Lao PDR in 2010 caused by Ralstonia solanacearum (sensu lato), as confirmed by (b) Positive Pocket Diagnostic ${ }^{\circledR}$ test kit
DNA was extracted from pure bacterial isolates using a Sigma REDExtract-N-Amp Plant PCR Kit. The 16S rDNA region was amplified using the $\mathrm{fD} 1$ and $\mathrm{rP} 2 \mathrm{PCR}$ primers. The endoglucanase $e g l$ gene was amplified using the primer pair Endo-F (5'-ATGCATGCCGCTGGTCGCCGC-3') and EndoR (5'-GCGTTGCCCGGCACGAACACC-3'). PCRs were performed in an Applied Biosystems Veriti Thermal Cycler in a total volume of $25 \mu \mathrm{L}$. The PCR mixtures contained $12.8 \mu \mathrm{L}$ of UV-sterilised ultra-filtered water, $2.5 \mu \mathrm{L}$ of $10 \times$ PCR buffer (with $20 \mathrm{mM} \mathrm{MgCl2}$ ), $5.0 \mu \mathrm{L}$ GC-RICH solution, $0.5 \mu \mathrm{L}$ of dNTPs (each $100 \mu \mathrm{M}), 1 \mu \mathrm{L}$ of each primer $(5 \mu \mathrm{M})$, $1 \mu \mathrm{L}$ of BSA $(10 \mu \mathrm{g} / \mu \mathrm{l}), 1 \mu \mathrm{L}$ of genomic DNA $(100 \mathrm{ng} / \mu \mathrm{l})$, and $0.2 \mu \mathrm{L}(1 \mathrm{U})$ of Roche FastStart Taq DNA Polymerase. The PCR conditions for $16 \mathrm{~S}$ were $4 \mathrm{~min}$ at $94{ }^{\circ} \mathrm{C}$, then $30 \mathrm{cy}-$ cles of $94{ }^{\circ} \mathrm{C}$ for $30 \mathrm{~s}, 50{ }^{\circ} \mathrm{C}$ for $30 \mathrm{~s}, 72{ }^{\circ} \mathrm{C}$ for $40 \mathrm{~s}$, and then $7 \mathrm{~min}$ at $72^{\circ} \mathrm{C}$. The conditions for the $e g l$ gene were $4 \mathrm{~min}$ at $94{ }^{\circ} \mathrm{C}$, then 35 cycles of $94{ }^{\circ} \mathrm{C}$ for $30 \mathrm{~s}, 60^{\circ} \mathrm{C}$ for $30 \mathrm{~s}, 72{ }^{\circ} \mathrm{C}$ for $40 \mathrm{~s}$, and then $7 \mathrm{~min}$ at $72{ }^{\circ} \mathrm{C}$. DNA sequences were obtained in both directions on an Applied Biosystems 3500xl.

Multiple sequence alignments were made with Geneious Pro v. 8.1.8. Bayesian inference was used to reconstruct the phylogenies using MrBayes v. 3.2.2 (Ronquist et al. 2012). Analyses were run twice for $2 \times 10^{7}$ generations. Sequences derived in this study were lodged in GenBank (16SrDNA KM216391, Egl-KP411760), alignments and supplementary data are available at http://doi.org/10.7931/J2QC01DV. Sequences of the gene endoglucanase $(e g l)$ were used in this study to provide a high level of discrimination of both species and phylotype (Fig. 4). The isolate of this study, ICMP 20038, is unambiguously identified as $R$. pseudosolanacearum (formerly $R$. solanacearum phylotype I).

A pathogenicity test was undertaken using six-week-old tomato seedlings from an organic seed farm in Paksong. The seedlings were transplanted into a soil mix consisting of two parts (by volume) of an alluvial soil that had no history of vegetable cropping, and one part sand, in small pots $(15 \mathrm{~cm}$ diam), and grown at air temperatures varying from 25 to 


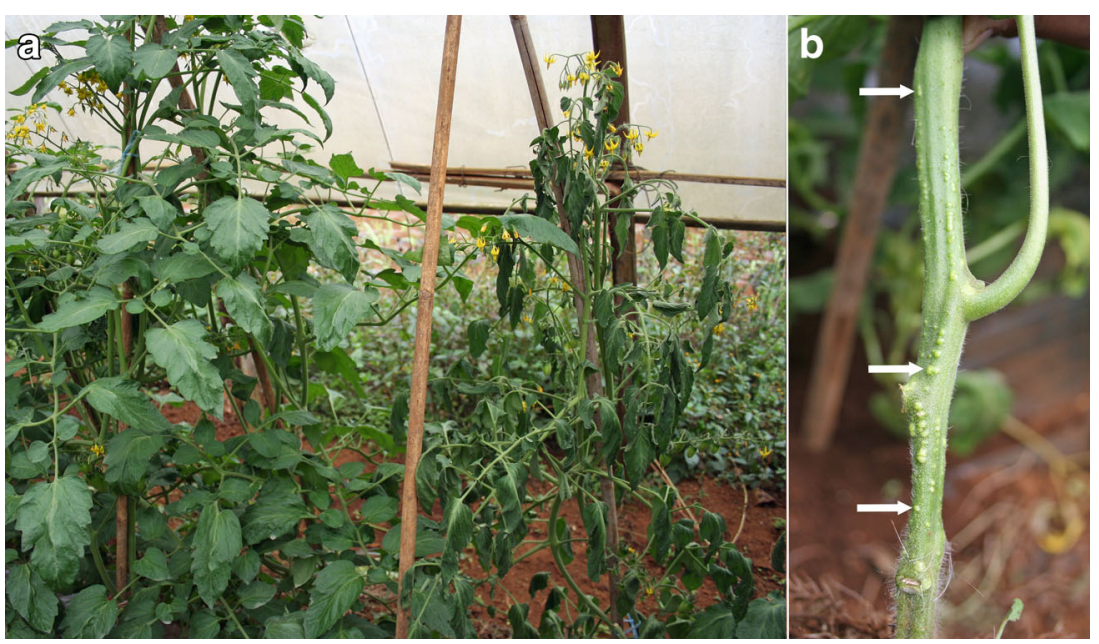

Fig. 3 Bacterial wilt symptoms caused by Ralstonia solanacearum (sensu lato) observed on tomato (Solanum lycopersicum) in Paksong District, Champasak province, Lao PDR in 2013. (a) Green wilt as observed in the plant on the right, with a healthy tomato plant on the left; and (b) Adventitious roots (indicated by white arrows) developing along the stem of the tomato plant

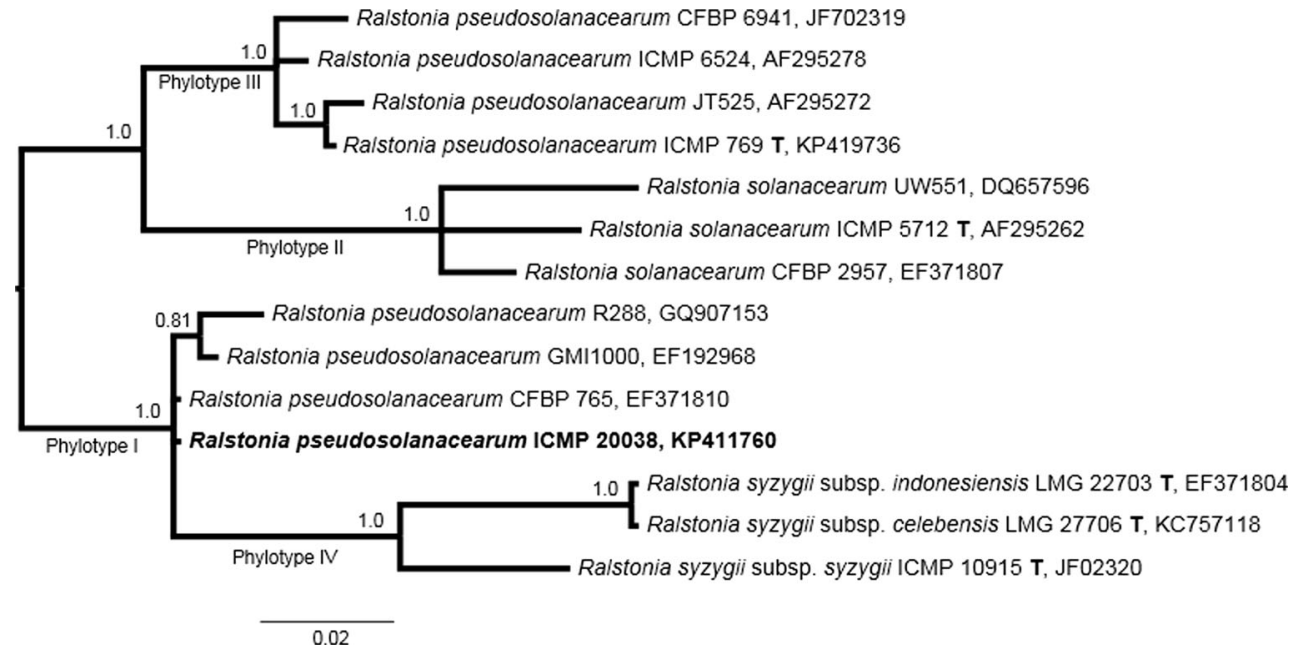

Fig. 4 Bayesian inference phylogenetic tree of $e g l$ gene sequences showing the relationship of Ralstonia pseudosolanacearum to related species. Posterior probabilities are shown above nodes. Strain numbers

$30{ }^{\circ} \mathrm{C}$. The alluvial soil was selected in order to provide a competitive soil microflora. There were four plants per pot. are indicated, followed by GenBank accession numbers. Type strains indicated by "T". The isolate of this study, ICMP 20038, is emphasised in bold font

Two weeks after transplanting, cultures of ICMP 20038 were used to prepare suspensions of bacterial cells at a concentration
Fig. 5 (a) Green wilt symptoms of inoculated plants (nonwounded and wounded) during a pathogenicity test, at 14 days after inoculation with Ralstonia pseudosolanacearum, as confirmed by (b) Positive Agdia ${ }^{\circledR}$ immunostrip assay for R. solanacearum (sensu lato)
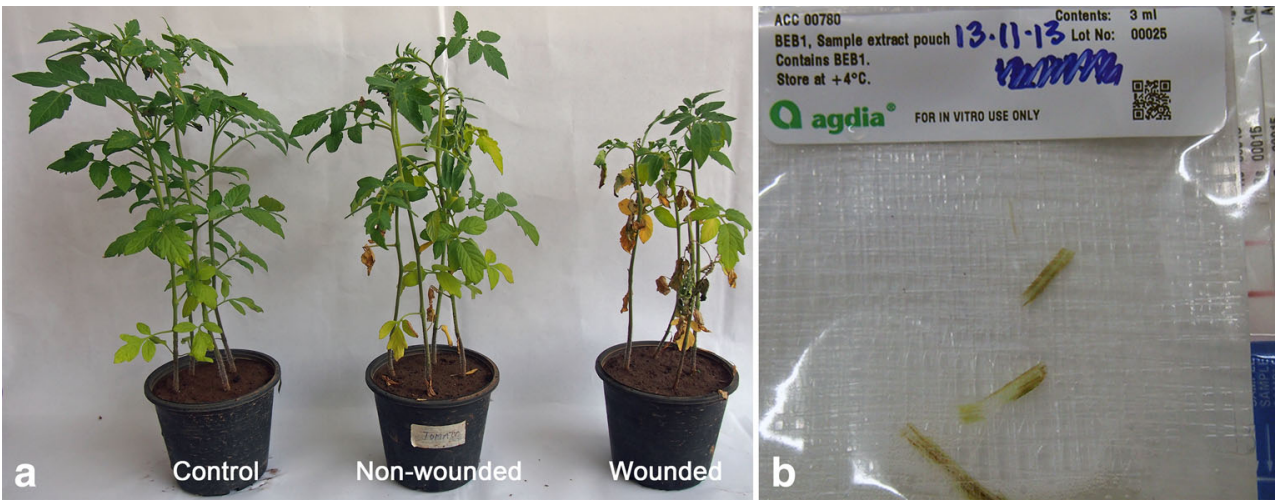
of approximately $5 \times 10^{6}$ to $5 \times 10^{7} \mathrm{CFU} \mathrm{ml}^{-1}$ in sterile water. In the first test, plants were inoculated by pouring $10 \mathrm{ml}$ of suspension per plant down the stem of the plant, starting approximately $10 \mathrm{~cm}$ from the growing tip of the plant. In this experiment, four plants (i.e. one pot) were wounded with a sterile hypodermic needle along the stem, below the inoculation point, while four plants were not. In the second test, a bacterial suspension made from re-isolations from the previous test was injected carefully into stems of plants until a small amount of inoculum exuded from the inoculation point. Sterile water was used to inoculate four plants in each test as a control. Once inoculated, the plants were covered with a moistened plastic bag for $24 \mathrm{hr}$ to aid infection with a high relative humidity environment.

Wilting and water-soaked lesion development, particularly at wound sites and at junctions with branches (as seen in the field), were observed as early as 5 days postinoculation. Adventitious root development above the lesions and inoculation points, again similar to that noted in the field, was also observed in at least a quarter of inoculated seedlings. All seedlings had wilted and/or presented with lesions and/or aerial roots by 14 days postinoculation (Fig. 5a). Ralstonia pseudosolanacearum was re-isolated using the same procedures as described above from both wounded and non-wounded tomato plants and identity within the $R$. solanacea rum (sensu lato) complex confirmed using an Agdia ${ }^{\circledR}$ field test kit (Fig. 5b), fulfilling Koch's postulates. Control plants did not develop symptoms (Fig. 5a), beyond hypersensitive responses close to the wound sites.

This is the first report of $R$. pseudosolanacearum in the Lao PDR. Symptoms consistent with bacterial wilt have also been observed in chilli and ginger at the large polyhouse farm near Paksong from where the samples of tomato were collected, indicating the possible presence of additional hosts of $R$. pseudosolanacearum in this region and potentially other phylotypes of $R$. pseudosolanacea rum and closely related species. Furthermore, symptoms consistent with bacterial wilt have also been observed in tomato in small-holder farms in Savannakhet city, a more northern location at close to sea level (145 m alt) and different agro-climatic region to the Bolaven plateau. The production of tomatoes on $R$. pseudosolanacearum and $R$. solanacearum (sensu lato) resistant root stock is being encouraged, and is already being applied by some larger farming cooperatives in the area. This is a highly technical task however, and will require targeted and sustained capacity building efforts to reach a wide range of both smallholder and commercial-scale farms. In the meantime, capacity building programs to encourage clean planting stock, farm hygiene ("come clean, go clean"), adequate destruction of infected crop residues and crop rotation is ongoing. Additional work to identify the full range of $R$. solanacearum (sensu lato) phylotypes and distinct species in the region, coupled with the testing of suitable rotation vegetable crops for tolerance and resistance, when assessed alongside the growing knowledge of plant pathogens known to cause pathologies on the plateau (Callaghan et al. 2016; Ireland et al. 2014) would be valuable to inform and assist future cropping options and integrated disease management strategies.

Acknowledgments Financial support from the Crawford Fund of Australia is gratefully acknowledged. The authors also acknowledge the support provided by the Champasak Provincial Agriculture and Forestry Office, and the Plant Protection Centre in Vientiane. The first author was an Australian Volunteer for International Development, the eleventh author was an Australian Youth Ambassador for Development, both Australian Government Programs, and the twelfth author was a Voluntary Service Overseas volunteer, a charity operating out of offices in the United Kingdom.

\section{References}

Burgess LW, Knight TE, Tesoriero L, Phan HT (2008) Diagnostic manual for plant diseases in Vietnam. ACIAR Monograph 129. ACIAR, Canberra

Callaghan SE, Williams AP, Burgess T, White D, Keovorlajak T, Phitsanoukane P, Phantavong S, Vilavong S, Ireland KB, Duckitt GS, Burgess LW (2016) First report of Phytophthora capsici in the Lao PDR. Aust Plant Dis Notes 11:1-4. doi:10.1007/s13314-0160210-9

Hayward AC (1994) The hosts of Pseudomonas solanacearum. In: Hayward AC, Hartman GL (eds) Bacterial wilt: the disease and its causative agent, Pseudomonas solanacearum. CAB International, Wallingford

Ireland KB, Weir BS, Phantavong S, Phitsanoukane P, Vongvichid K, Vilavong S, Tesoriero LA, Burgess LW (2014) First report of Rhizoctonia solani anastomosis group AG-4 HG-I in the Lao PDR. Australa Plant Dis Notes 10. doi:10.1007/s13314-014-0152-Z

Kelman A (1953) The bacterial wilt caused by Pseudomonas solanacearum: a literature review and bibliography. North Carolina Agricultural Experiment Station Technical Bulletin 99

Nesmith WC, Jenkins SF (1985) Influence of antagonists and controlled matric potential on the survival of Pseudomonas solanacearum in four North Carolina soils. Phytopathology 75:1182-1187. doi:10.1094/Phyto-75-1182

Ronquist F, Teslenko M, van der Mark P, Ayres DL, Darling A, Höhna S, Larget B, Liu L, Suchard MA, Huelsenbeck JP (2012) MrBayes 3.2: efficient bayesian phylogenetic inference and model choice across a large model space. Syst Biol 61:539-542. doi:10.1093 /sysbio/sys029

Safni I, Cleenwerck I, De Vos P, Fegan M, Sly L, Kappler U (2014) Polyphasic taxonomic revision of the Ralstonia solanacearum species complex: proposal to emend the descriptions of Ralstonia solanacearum and Ralstonia syzygii and reclassify current $R$. syzygii strains as Ralstonia syzygii subsp. syzygii subsp. nov., $R$. solanacearum phylotype IV strains as Ralstonia syzygii subsp. indonesiensis subsp. nov., banana blood disease bacterium strains as Ralstonia syzygii subsp. celebesensis subsp. nov. and $R$. solanacearum phylotype I and III strains as Ralstonia pseudosolanacearum sp. nov. Int J Syst Evol Microbiol 64:30873103. doi:10.1099/ijs.0.066712-0 